Contents List available at RAZI Publishing

Pakistan Journal of Geology (PJG)

Journal Homepage: http://www.razipublishing.com/journals/pakistanjournal-of-geology-pjg/

\title{
Microfacies Analysis and Resrvoir Potential of Sakesar Limestone, Nammal Gorge (Western Salt Range), Upper Indus Basin, Pakistan
}

\author{
Zain Ur Rahman, Zawar Muhammad Khan, Zeeshan Khattak, Muhammad Azam Abbas*, Muhammad Ishfaque² \\ *Department of Earth and Environmental Sciences, Bahria University Islamabad, Pakistan \\ 2 Institute of Geology, The university of Azad Jammu and Kashmir, Muzaffarabad, Pakistan
}

This is an open access article distributed under the Creative Commons Attribution License, which permits unrestricted use, distribution, and reproduction in any medium, provided the original work is properly cited

\section{ARTICLE DETAILS}

Article history:

Received 24 October 2016 Accepted 7 December 2016 Available online 3 January 2017

Keywords:

Sakesar Limestone; Namma Gorge; Microfacies Analysis; Bioclastic Wackestone;

Diagenesis; Reservoir Potential

\section{ABSTRACT}

The sedimentological study of the Lower Eocene Sakesar Limestone in Nammal gorge section, Western Salt Range, was carried out to elaborate the microfacies, diagenetic settings and reservoir potential. The Sakesar Limestone is widely distributed across the Salt and Surghar ranges. It mainly consists of massive and nodular fractured limestone with subordinate marls and chert in the upper part. The Eocene succession is only comprised of conformable Sakesar Limestone and Nammal Formation in Nammal gorge. The detailed study was conducted after measuring the vertical thickness of $18 \mathrm{~m}$ section and the 6 six samples were obtained symmetrically. To give the detailed insight of sedimentological characteristics the well cuttings of Sakesar Limestone from well Pindori-01, were studied along with the un-stained thin sections to investigate the microfacies, diagenesis and reservoir potential. The well cuttings study revealed that the Sakesar Limestone is off white to dull grey calcite, moderately hard with cryptocrystalline to microcrystalline silica along with pyrite. Detailed field observations and laboratory investigations revealed that it contains Bioclastic wackstone microfacies. Neomorphism is present in various bioclasts. The presence of fractures filled with waxy leftover hydrocarbons makes it potential target for hydrocarbons. Petrophysical analysis shows an average hydrocarbon saturation of 85.5 percent in well Pindor-01 which confirms the huge reservoir potential of Sakesar Formation. Microfacies analysis indicates high lime mud and low faunal diversity which led towards the conclusion that the Eocene Sakesar Limestone was mainly deposited in semi restricted, low energy shallow marine shelf environment.

\section{Introduction}

The study section is located in the Nammal gorge (Western Salt Range) near Nammal Lake. The study area is located at the latitude of $32^{\circ} .66472 \mathrm{~N}$ and longitude of $71^{\circ} .802483 \mathrm{E}$. It is situated in the western part of the Potwar fold and thrust belt and lies in Mianwali District, Punjab (Fig. 1).The area is easily accessible from Islamabad through M-1 linked with Mianwali-Talagang road. The Pindori Oilfield is located in the southeast of Potwar Basin that is about $67 \mathrm{~km}$ southwest of Rawalpindi in the Punjab Province. The Pindori structure is about $16 \mathrm{~km}$ northwest of Turkwal field and $18 \mathrm{~km}$ west of Bhangali field. The study area is located at the latitude of $33^{\circ} .24112 \mathrm{~N}$ and longitudes of $72^{\circ} .93372 \mathrm{E}$. It is situated in the eastern part of the Potwar fold and thrust belt and lies in Rawalpindi District, Punjab (Fig. 1). The area is easily accessible through road from Islamabad.

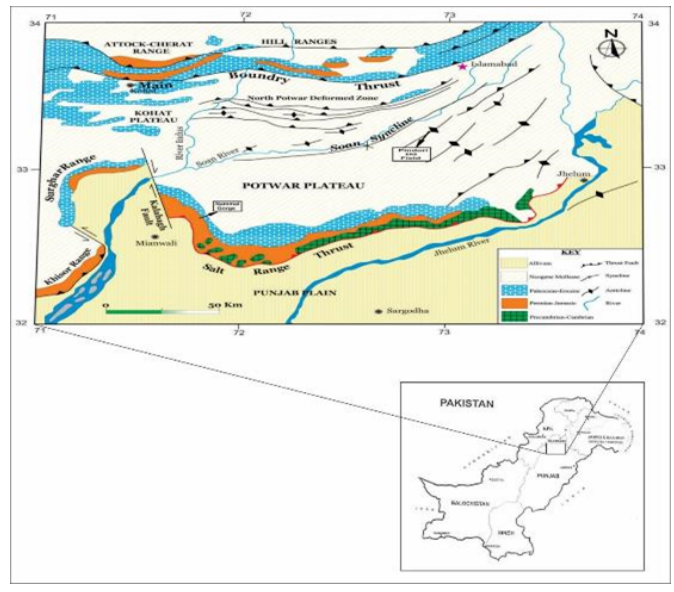

Fig. 1 Locations of Nammal gorge and Pindori oil field (after Kazmi and Rana, 1982; Jaswal et al., 1997).

Davies and Pinfold (1937) reported a larger foraminiferal assemblage including Nummulities mamillatus, (Fichtel and Mol, 1798), Nummulities atacicus (Leymerie, 1846), Assilina granulosa, Assilina spinose (Davies and Pinfold, 1937), Lockhartia tipperi (Davies, 1932) and Alveolina globose (Leymerie, 1846). Many authors measured this section (Haque, 1956; Jurgan et al; 1989 partly, Wardlaw et al; 1991) and some investigated its biostratigraphy (Haque, 1956; Haq, 1971). Sameeni (1997) identified a new Alveolinid foraminifer's assemblage in Sakesar Limestone at Nammal, Western Salt Range. Boustani and Khawaja (1997) studied microfacies of Sakesar Limestone in Central Salt Range, Pakistan and reported two microfacies i.e., wackestone and packstone. He divided these facies into further six-subfacies ( Nizami et al., 2010) conducted a detailed study for the diagenetic fabric and microfacies assemblages of Sakesar Limestone in Central Salt Range. The two facies bioclastic wackestone and bioclastic packstone were identified. The work reported the number of benthonic foraminiferal species, dissolution, replacement, alteration, dolomitization, micritization, various cement morphologies, micritic envelope, open and filled fractures (calcite veins), stylolites and solution porosities. The studies revealed that the Sakesar Limestone was mainly deposited in subtidal and intertidal zone of shelf and a small part deposited in restricted environment. Nazir et al. (2013) conducted a detailed study for the sedimentology and reservoir potential of Eocene Sakesar Limestone in Eastern Salt Range. The identified microfacies were mainly bioclastic wackestone, packstone, wackestone to packstone and packstone to grainstone. He observed repetition of these zones at various levels. The various cement types and dolomitization as a replacement were recorded. The depositional environment was marked as shallow shelf environment with high secondary porosity and reservoir potential. Ahmed et al. (2014) worked on microfacies, diagenesis and reservoir characterization of Sakesar Limestone in Western Salt Range. He studied three sections (Dhak Pass, Zaluch Nala) 
The reported three microfacies include larger benthic foraminiferal wackepackstone, foraminiferal-algal wacke-packstone, and Brachiopod rich bioclastic wacke-packstone facies. He suggested that the Sakesar Limestone was deposited in inner to middle ramp lagoonal environment. The diagenesis is mainly constrained by microfacies. Features such as stylolite, calcitization, neomorphism, nodularity, various cement types (blocky, fibrous, granular mosaic, bladed, drusy mosaic and equant isopachous) and fracturing are present in majority of the samples. These features indicated marine to meteoric to burial environment. The porosity studies indicated the large reservoir potential of Sakesar Limestone.

\section{Methodology}

The field visit to Nammal gorge, Western Salt Range was commenced for the sample collection from the Eocene Sakesar Limestone. On the basis of continuity of exposure, datum horizon, geological observations and characteristic features, the Sakesar Limestone was marked conformably lying over the Nammal Formation alongside the Nammal Dam. The measuring tape was used to measure the exposed thickness of the Formation which was about $18 \mathrm{~m}$. The total six lithological samples were collected from equal intervals of $3 \mathrm{~m}$. On the basis of detailed geological field observations the lithology log was prepared. In addition to outcrop samples the well cuttings data was used for the detailed lithological characteristic of the Sakesar Limestone from wells of Pindori Oil Field in the Eastern Potwar, where the Sakesar Limestone is acting as the potential reservoir. The data accessibility was solely made possible by the operator company Pakistan Oil Fields Limited. The well logs data of Pindori-01 was used for the reservoir characterization. A total of 12 thin sections were prepared from 6 samples to give insight the fossils, microfacies, diagenetic fabric, porosity evaluation and the environment of deposition for the Sakesar Limestone by using petrographic studies as a tool. The relative portion of bioclastic material to the matrix in individual thin section was determined by visual percentages. The Dunham scheme (1962) was used to classify the rock types and these rock types were considered as the micro facies. The identified standard microfacies were compared with microfacies classification scheme of Flugel (2004) to find the depositional environment of the Sakesar Limestone. The micro faunal assemblage depth ranges were plotted on a chart to enhance the details for depositional environment. The well cuttings have been examined under the microscope to enhance the detail of sedimentological work and reservoir characterization. The well logs data from the above mentioned wells was interpreted by using PRIZM (GeoGraphix Suite) for the reservoir characterization of Sakesar Limestone.

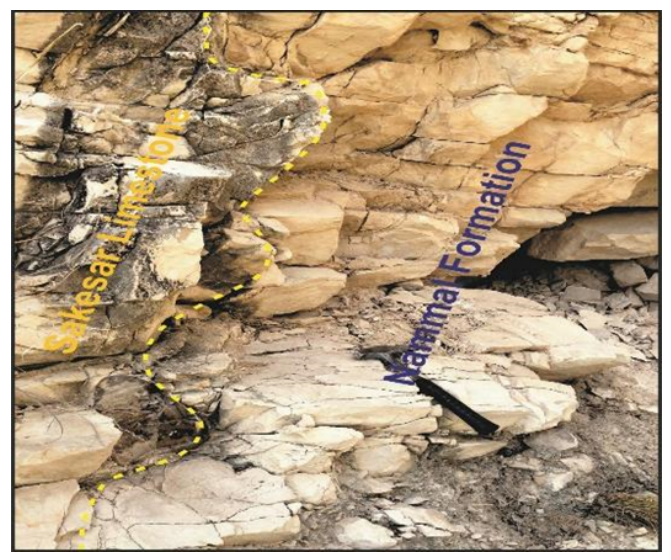

Fig. 2 Conformable contact between Eocene Nammal Formation and Sakesar Limestone, Nammal gorge, Western Salt Range, Mianwali, Pakistan.

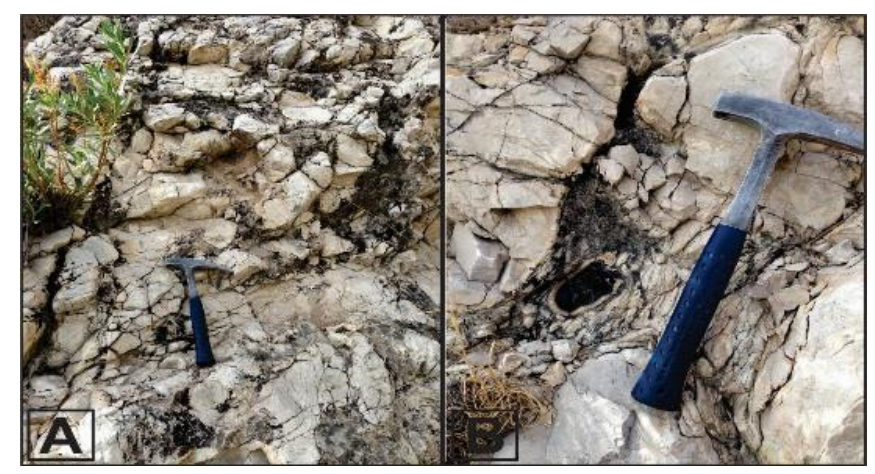

Fig.3 a) Photograph of weathering, nodularity and fracturing (b) Photograph of chert nodule in Sakesar Limestone.

\section{Field work and observations}

On the basis of field observations the lithology log has been prepared. Total six samples were collected from the exposure after measuring the thickness of outcrop (Fig. 3.2 A and B). The log is comprised of the notable observations of the exposed section including sample number, color, lithology, compaction, softness, fossils, diagenetic features and photographs (Fig. 5).

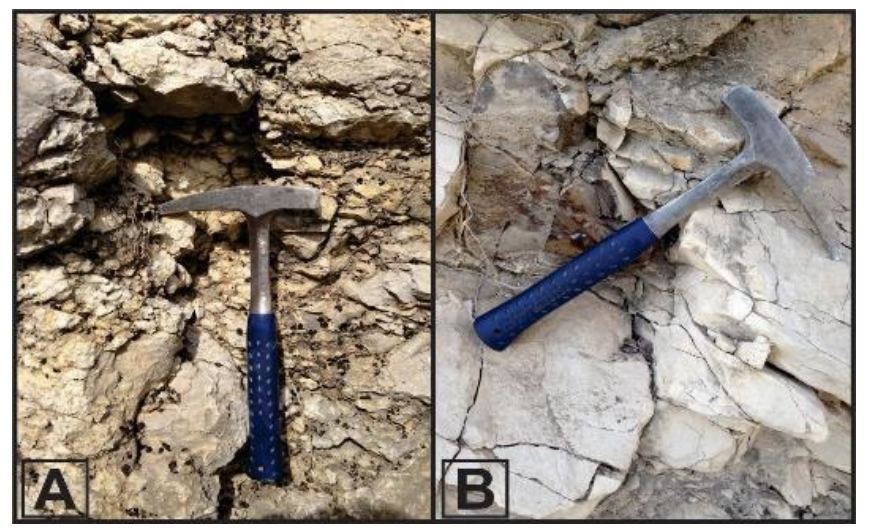

Fig. 4(a) Photograph of weathering (b) Photograph of diagenetic pyrite in Sakesar Limestone.

The Eocene Sakesar Limestone is exposed alongside the Nammal Dam in Western Salt Range. The thickness of the exposed Sakesar Limestone is $18 \mathrm{~m}$. Lithological characteristics are comprised of off white to grey color weathered limestone with nodularity and the chert nodules present in it (Fig. 3). The limestone is fossiliferous. Diagenetic Pyrite leaching and fracturing were observed throughout the formation (Fig. 4). It has conformable contact with underlying Nammal Formation In Eastern and Central Salt Range the complete Eocene succession is present whereas in Western Salt Range the Lower Eocene is present comprising of conformable Nammal Formation and Sakesar Limestone

(Fig. 2). The thickness of the formation varies across the Salt Range.

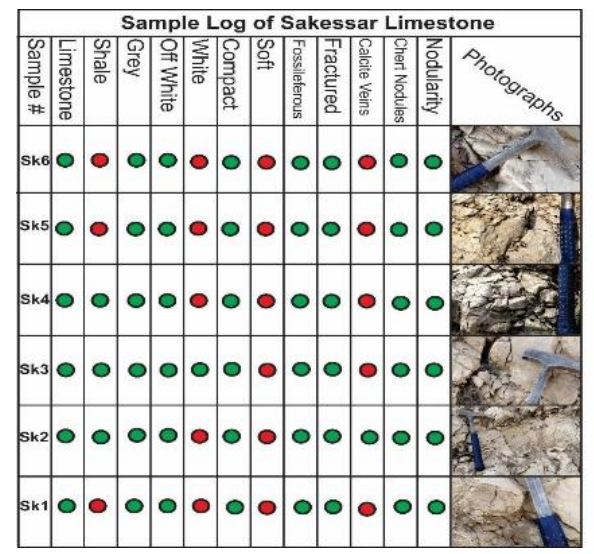

Fig. 5 Sample collection log of Sakesar Limestone (Nammal gorge).

\subsection{Well cuttings petrography}

The Sakesar Limestone is off white to creamy white, brownish grey, light olive grey, light to medium grey in color. It is soft to moderately hard. The microcrystalline-cryptocrystalline silica is found which is distinguished from transparent calcite grains by lack of cleavage surfaces. This silica content is from crushed chert nodules moderate aragonite content is also observed. The broken fragments of forums including broken shell fragments have been found, no complete faunal grains is retrieved due to very fine size cuttings because of the use of PDC bit in drilling phase. The pyrite inclusions are also present in some intervals (Fig. 6). The pyrite formation in the sedimentary rocks is formed during the diagenesis process when the microbial activity takes place between the pore spaces in the reducing environments. 

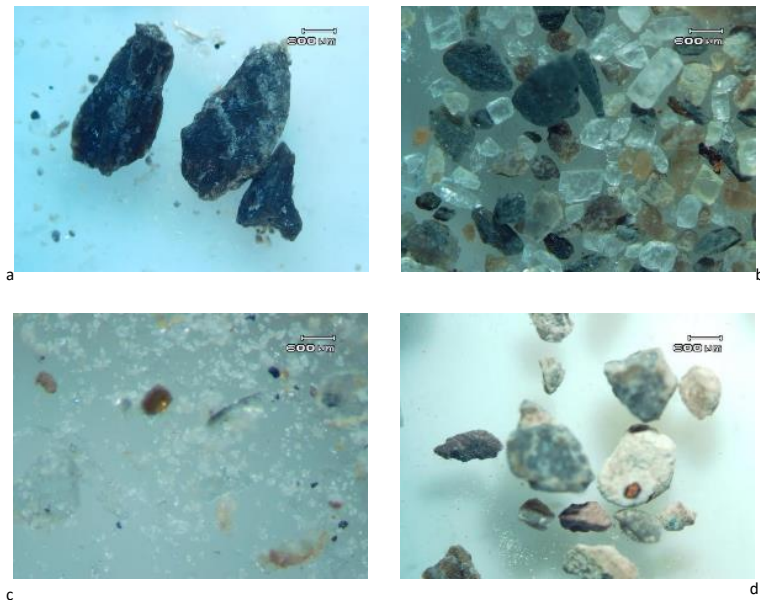

Fig. 6 Photomicrographs of well cuttings from Sakesar Limestone. (a) brownish grey calcite grains, (b) calcite grains of transparent, light grey to dull grey and light brown color, cryptocrystalline silica in transparent color and pyrite traces , (c) golden brown pyrite grain with calcite and muscovite mica flakes and (d) calcite in off white, milky white to creamy white color with pyrite inclusion.

\subsubsection{Bioclastic Wackestone microfacies (SK 1, SK2, SK3, SK4, SK5, SK6)}

Bioclastic wackestone microfacies is identified by the petrographic study of all the thin sections of Sakesar Limestone, collected from Nammal Gorge section. Microfacies is characterized by wackestone depositional textures. The biogenic content is poorly preserved and the bioclasts abundance ranges from 10-30\%, with an average of $20 \%$. The micritic matrix ranges from 70 to $90 \%$ with an average of $80 \%$. The dominant allochems are larger benthic foraminifera i.e. Nummulites, Assilina, Lockhartia,

Discocyclina and Ranikotalia. The average relative abundance of the biogenic grains is: Nummulites (8\%), Assilina (3\%), Lockhartia (7\%), Discocyclina (6\%), and Ranikotalia (1\%).

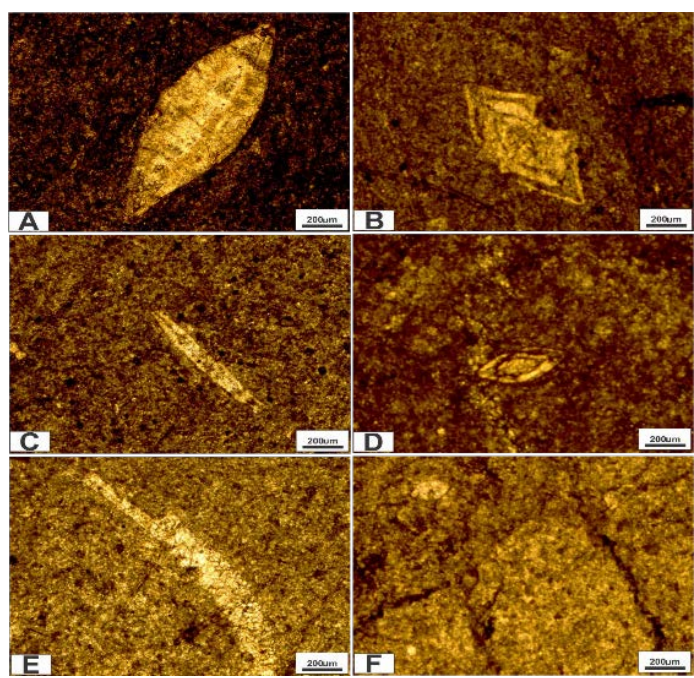

Fig. 7 Bioclastic Wackestone Microfacies (Sk 1). The microfossils include Assilina laminosa (A), Assilina subspinosa (B), Ranikotalia sp (C), Nummulities mamillatus (D), dolomitization phenomena in bioclast (E) and network of fractures and a bioclast (F).

\subsubsection{Identified microfacies in Eocene Sakesar Limestone}

The microfacies analysis with the help of thin sections studies has been carried out. A total of six figures of photomicrographs have been prepared from 6 samples, each consists of 2 thin section. The microfacies identified after detailed examination is Bioclastic Wackestone microfacies.

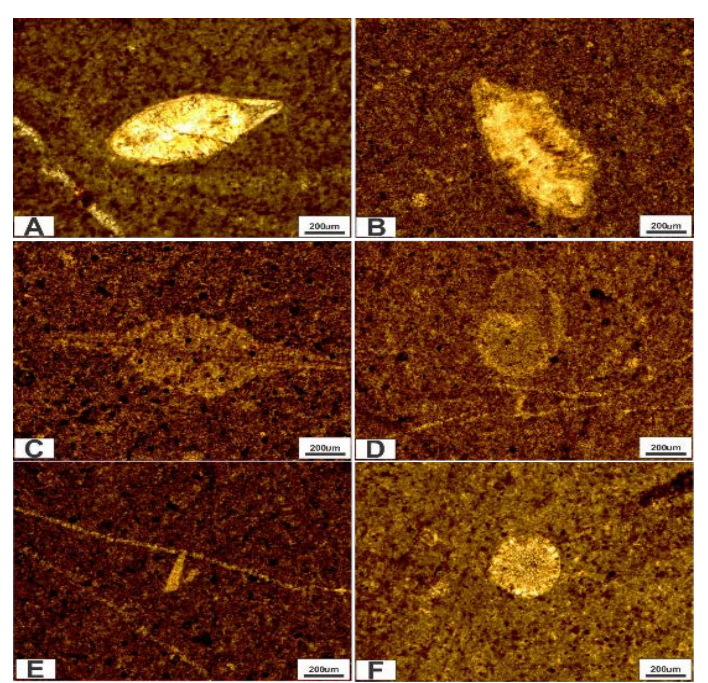

Fig. 8 Bioclastic Wackestone Microfacies Sk 2. The microfossils include Discocyclina dispansa with neomorphism along fracture and a calcite vein (a), Lockhartia tipperi (b), Discocyclina marginata (c),Mollusk gastropod preserved as a cast partially replaced by matrix (d), bioclast and calcite veins (e) and Echinoderm spine (f)

\subsection{Diagenesis}

3.2.1 Neomorphism

Neomorphism is the in-situ replacement and recrystallization of aragonite shell with calcite. In Sakesar Limestone the process of neomorphism is clearly visible at many places. The feature can be seen in (Fig. 11).

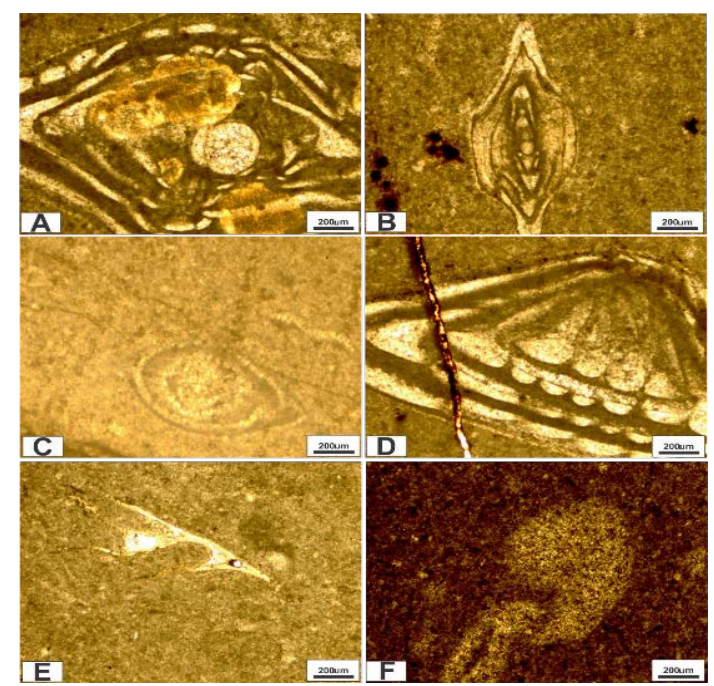

Fig. 9 Bioclastic Wackestone Microfacies (Sk 6). The microfossils include Nummulities sp with pyritization (a), Discocyclina sp and pyrite (b), Miliolid $\mathrm{sp}$ (c), Fractured Lockhartia haimei filled with calcite and pyrite (d), bioclast with neomorphism (e) and partially dissolved bioclast (f).

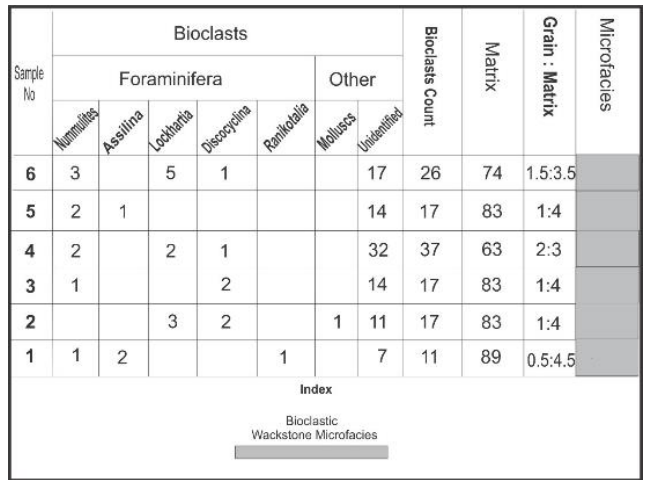

Fig. 10 Identified microfacies of Eocene Sakesar Limestone. 
Cite this article as: Zain Ur Rahman, Zawar Muhammad Khan, Zeeshan Khattak, Muhammad Azam Abbas*, Muhammad Ishfaque ${ }^{2}$ Microfacies Analysis and Resrvoir Potential of Sakesar Limestone, Nammal Gorge (Western Salt Range), Upper Indus Basin,Pakistan Pakistan Journal of Geology(PJG)

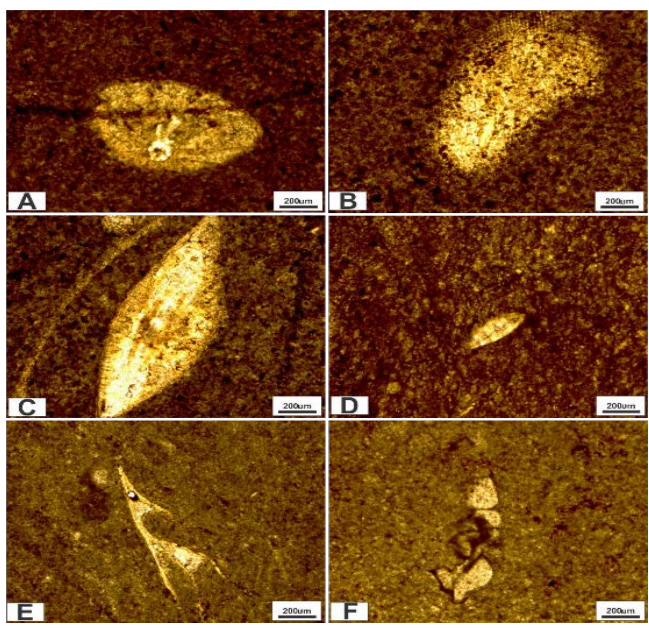

Fig.11 Neomorphism in various bioclasts in Sakesar Limestone (A-F).

\subsubsection{Fractures}

In Sakesar Limestone the fractures are found at different horizons in the measured section. The presence of these fractures, broken allochems and veins depicts the overburden pressure and the tectonic stresses both pre-and-post lithification phases. Some fractures are partially filled with calcite. These fractures mark the secondary porosity and indicate the reservoir potential of the Formation. The fracturing is shown in all photos of (Fig. 12).

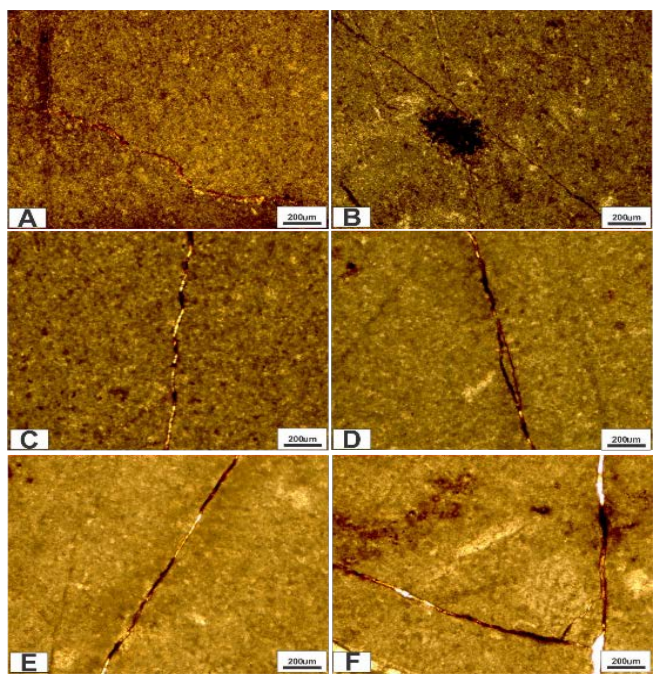

Fig.12 Fractures in Sakesar Limestone. Fractures are partially filled with calcite and organic matter found in all samples (A-F).

\subsubsection{Diagenetic pyrite}

The pyrite is present at different horizons in the Eocene Sakesar Limestone at Nammal Gorge section. The sedimentary diagenetic pyrite is formed by microbial processes under reducing conditions. Pyrite grains of age ranging from Archean to Jurassic have been examined by scanning and transmission electron microscopes, mostly showed the coccoid, rod shaped and filamentous features which are interpreted as microbial (Schieber, 2002). The pyrite formation takes place close enough to the sediment surface, when the pore spaces are being teemed with microbes (Canfield and Raiswell, 1991; Bird et al., 2001). The preservation of the soft tissues structures is well known from geologic record (Allison and Briggs, 1991), it can actually be expected that the bacteria favored the pyrite formation in reducing conditions. 1(1) (2017) 12-17

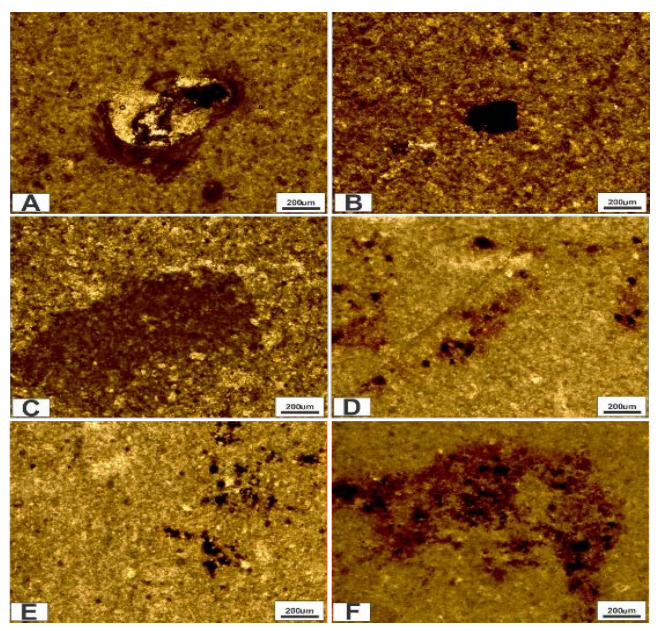

Fig.11 Neomorphism in various bioclasts in Sakesar Limestone (A-F).

With sedimentary rocks having diagenetic pyrite, there is great potential for the recovery of microbial fossils and a wide range of environments. The diagenetic pyrite is shown in (Fig. 13).

\subsection{Depositional environment of Eocene Sakesar Limestone}

The microfacies is characterized by lime mud, lack of diversity of organisms and restricted fauna, which suggests that microfacies is interpreted to have been deposited in a restricted environment on the inner shelf. The microfacies is similar to Standard Microfacies (SMF) 19 of Wilson (1975) and Flügel (1982). Fossils include some foraminifera, mollusk cast and echinoderm spine. The microfacies represent partially restricted inner shelf lagoon (Fig. 14).

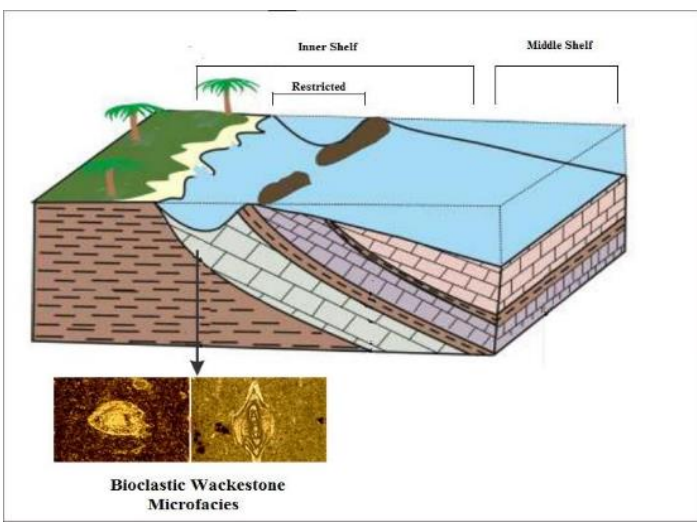

Fig. 14 Depositional model of microfacies of Sakesar Limestone.

The micro faunal depth ranges show that the Eocene Sakesar Limestone is deposited between $10 \mathrm{~m}$ to $120 \mathrm{~m}$ deep. The depth range indicate the shallow marine region and the low energy depositional environment for the Sakesar Limestone (Fig. 15).

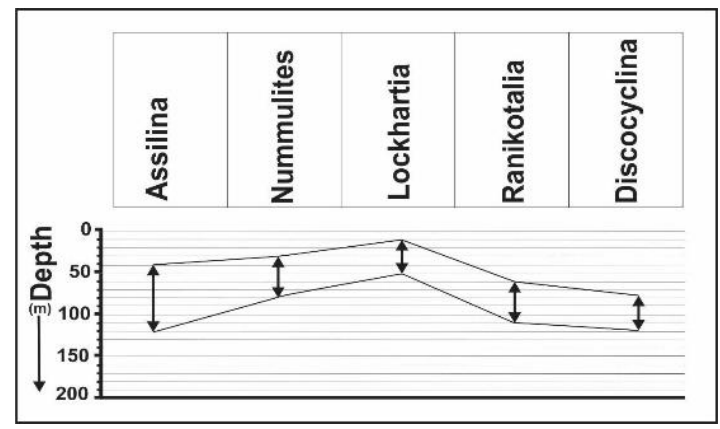

Fig. 15 Depth ranges of foraminifer's assemblages of Sakesar Limestone (Sameeni, 1997).

3.4 Log analysis

3.4.1 Marking suitable reservoir zone

The reservoir zone of 16 meter from 4076 m to $4091 \mathrm{~m}$ in Eocene 
Sakesar Limestone in well Pindori-01 has been marked. The zone is marked on the basis of parameters including (fair borehole conditions, low GR, Sp deflecting on lower side, separation between LLS and LLD indicating permeability, Gas effect (the cross-over between NPHI and RHOB).

\subsection{Petrophysical analysis}

The reservoir zone of $16 \mathrm{~m}$ is comprised of mainly limestone with very low volume of shale $6.68 \%$ which approaches to zero in the middle of zone. The sonic porosity is calculated for the zone which is not much higher, just only $4.54 \%$ whereas the effective porosity is $4.24 \%$. The zone shows the very good saturation of hydrocarbon with $85.85 \%$ and the rest $14.15 \%$ is water. The results show that the Eocene Sakesar Formation has great reservoir potential (Table.1).

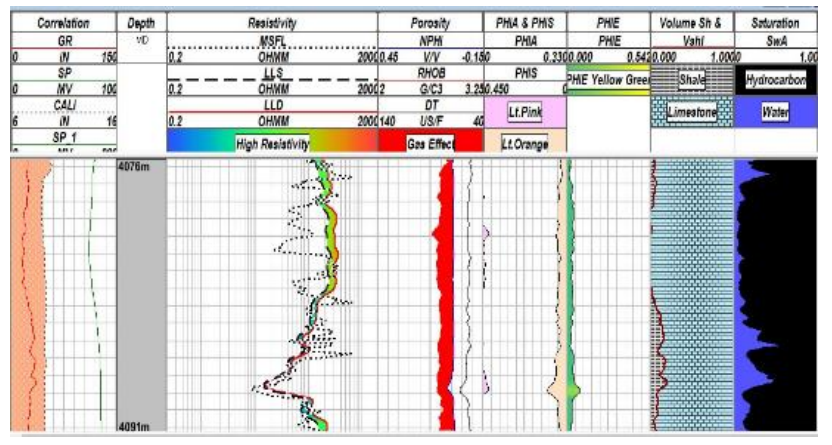

Fig.16. Petrophsyical analysis of Eocene Sakesar Limestone well Pindori-01.

Table. 1 Log readings of reservoir zone of Pindori-01.

\begin{tabular}{|l|l|l|l|l|l|}
\hline Depth $(\mathrm{m})$ & Vshale \% & Phi S \% & Phi E \% & Sw & Sh \% \\
\hline 4076 & 5.2 & 2.6 & 2.4 & 23.6 & 76.4 \\
\hline 4077 & 7.7 & 3.7 & 3.5 & 8.1 & 91.9 \\
\hline 4078 & 4.3 & 4.1 & 4.1 & 10 & 90 \\
\hline 4079 & 0 & 4.7 & 4.7 & 4 & 96 \\
\hline 4080 & 0 & 4.9 & 4.9 & 4.4 & 95.6 \\
\hline 4081 & 0 & 3.4 & 3.4 & 7.9 & 92.1 \\
\hline 4082 & 0 & 3.9 & 3.9 & 6.7 & 93.3 \\
\hline 4083 & 0.5 & 4.2 & 4.1 & 6.3 & 93.7 \\
\hline 4084 & 6.7 & 4.4 & 4.1 & 12.6 & 87.4 \\
\hline 4085 & 12.6 & 4.7 & 4.7 & 11.9 & 88.1 \\
\hline 4086 & 16.2 & 4.1 & 3.4 & 28.7 & 71.3 \\
\hline 4087 & 17.4 & 5.7 & 4.7 & 16.8 & 83.2 \\
\hline 4088 & 11.8 & 5.2 & 4.6 & 41 & 59 \\
\hline 4089 & 9.3 & 9.5 & 8.6 & 12.1 & 87.9 \\
\hline 4090 & 8.6 & 4.2 & 3.9 & 19.2 & 80.8 \\
\hline 4091 & 6.6 & 3.4 & 3.2 & 13.1 & 86.9 \\
\hline Total & 6.68 & 4.54 & 4.26 & 14.15 & 85.85 \\
\hline
\end{tabular}

\subsection{Conclusions and Recommendations}

The Eocene Sakesar Limestone is comprised of Bioclastic Wackestone facies. The bioclasts are mainly the broken shell fragments and foraminifera including Assilina, Lockhartia, Discocyclina, Ranikotalia, and Nummulities. Some bioclasts are broken and fractured, which are the result of abrasion and increased tectonic stresses. In Sakesar Limestone the process of neomorphism is clearly visible at many places indicating the in-situ replacement of aragonite with calcite material.

In Sakesar Limestone the fractures are present at different horizons in the measured section. These fractures mark the secondary porosity and are filled with waxy leftover hydrocarbon which reveals that the Sakesar Limestone is a potential reservoir. The diagenetic pyrite presence at various horizons indicate that the Sakesar Limestone is deposited in restricted and reducing environment. The microfacies analysis and diagenetic settings indicate the high lime mud and low faunal diversity, which suggest that the Sakesar microfacies were deposited in restricted conditions of inner shelf (Shallow marine). The petrophysical analysis of well Pindori-01 indicate that the Eocene Sakesar Limestone has very good reservoir potential with average hydrocarbon saturation of $85.85 \%$. The fractures in Sakesar Limestone are filled with waxy leftover hydrocarbons, which indicate it as potential reservoir rock, if structure is present in any area, this formation can be targeted for hydrocarbons.The diagenetic pyrite in Sakesar Limestone needs Scanning electron microscopy and Transmission electron microscopy to find out the microbial origin of pyrite

\section{References}

[1] Ahmad, S., Zia, S., Hanif, M., Kamran, A., 2014. Microfacies, diagenesis and reservoir characterization of Sakesar Limestone Salt Range, Pakistan. Earth Sciences Pakistan, 29-31 August, 2014.

[2] Ahmed, N., Sameeni, S.J., Ahsan, N., 2013. Sedimentology and Reservoir Potential of the Lower Eocene Sakesar Formation of Dandot Area, Eastern Salt Range, District Chakwal, Pakistan. Science International (Lahore), 25(3): 521-529p.

[3] Bird, D.F., Juniper, S.K., Ricciardi- Rigault M., Martineu, P., Prairie, Y.T., Calvert, S.E., 2001. Subsurface viruses and bacteria in Holocene/ Late Pleistocene sediments of Saanich Inlet, B.C.: ODP Holes 1033B and 1034B, Leg 169S: Marine Geology, 174: 227-239p.

[4] Boustani, M., Khawaja, A. A., 1997. Microfacies Studies of Sakesar Formation Central Salt Range, Pakistan. Geology Bulletin University of Peshawar, 30: 131-142p.

[5] Canfield, D. E., Raiswell, R., 1991. Pyrite formation and fossil preservation in Allison, P.A., and Briggs, D.EG. eds., Taphonomy: Releasing the Data Locked in Fossil Record: New York, Plenum Press, 337-387p.

[6] Davies. L.M., Pinfold, E. G., 1937. The Eocene beds of the Punjab Salt Range, India, Geological Survey Memoirs Palaeontology India, New Series, 24: 79p.

[7] Davies, L.M., 1932. The genera dictyoconoides Nuttal, Lockhartia nov. and rotalia Lamarck. Trans. Royal Society, Edinburgh, 57: $407 \mathrm{p}$.

[8] Dunham, R.J., 1962. Classification of Carbonate Rocks According to Depositional Texture, In: Classification of Carbonate Rocks, American Association of Petroleum Geologists Memoirs, 1: 108-121p.

[9] Fatmi, A.N., 1973. Lithostratigraphic units of the Kohat-Potwar Province, Indus Basin, Pakistan: Geological Survey of Pakistan Memoirs, 10: $80 \mathrm{p}$.

[10] Fatmi, A.N., Akhtar, M., Alam, G.S., Hussain, I., 1984. Guide Book to Geology of Salt Range, First Pakistan Geological Congress Lahore, Geological Society of Pakistan, 14p.

[11] Farah, A., Lawerence, R. D., De jong. K. A., 1984, "An Overview of the Tectonics of Pakistan", in Haq, B. U. and Millimn, J. P, Marine Geology and Oceanography of Arabian Sea and Coastal Pakistan, Van No strand and Reinhold Co. and Scin. and Academic Editions, New York, 161-176p.

[12] Fichtel, I., Moll, J.P.C., 1982. Testaceamicroscopica. Pp. 53-54. Flugel, E. Microfacies Analysis of Limestones, Springer Verlag, Berlin, Germany, 1-633p.

[13] Flügel, E., 2004. Microfacies of Carbonate Rocks: Analysis, Interpretation and Application. Springer-Berlin, Heidelberg, New York, 657-623p.

[14] Folk, R.L., 1959. Practical petrographic classification of limestones. Bulletin American Association of petroleum Geologists, 43: 1-38p.

[15] Haque, A.F.M., 1956. The smaller foraminifera of the Ranikot and Laki of the Nammal Gorge, Salt Range.- Geological Survey of Pakistan, Memoirs, Quetta, 1:300p.

[16] Iqbal, M.W.A., Shah, S. M. I., 1980. A Guide to the Stratigraphy of Pakistan, GSP, 53: 9p.

[17] Kadri, I.B., Abid, M.S., 1986. Geology of Hydrocarbon Accumulation in Pakistan" 6th Off-shore South East Asia Conference, Singapore, $23 \mathrm{p}$.

[18] Kazmi, A.H., Jan, M.Q., 1997. Geology and Tectonics of Pakistan; Graphic Publishers, Karachi. Pakistan and R.A. Rana, 1982. Tectonic map of Pakistan, bf. Ed., Geological Survey Pakistan, Scale 1:2, 000,000, Quetta.

[19] Khan, M.A., Ahmed, R., Raza, H.A., Kernal, A., 1986. Geology of Petroleum in Kohat-Potwar depression, Pakistan. American Association 
of Petroleum Geologists, Bulletin, 70: 396-414p.

[20] Latif, M.A., 1970. Explanatory notes on the geology of Southeastern Hazara, to accompany the revised Geological Map, Wein Jb. Geol. B. A., Sonderb. 15: 5-20p.

[21] Leymerie, A., 1846. Memoir sur le terrain a nummulites des Corbiercs. Memoirs Society Geology France, 2 (1): 337-373p.

[22] Lillie, R.J., Johnson, G.H., Yousaf., Zamin, A.S.H. Yeats, R.S., 1987. Structural development within the Himalayan foreland foldthrust belt of Pakistan. In: Beaumont and Tankard (eds) Sedimentary Basins and Basin forming Mechanism. Canadian Society of Petroleum Geology, Memoir, 12: 379-392p.

[23] Nizami, A.R., Qayyum. A., Shabaz. A., 2010. Microfacies Assemblages and diagenetic framework of the lower Eocene Sakesar Formation Karoli Area, Central Salt Range, Sub-Himalayas of Pakistan. Journal of Himalayan Sciences, 43: 66p.

[24] Sameeni, S.J., Butt, A.A., 1997. Foraminifera from the Lower Eocene Sakaser Limestone of Nammal area, Western Salt Range, Northern Pakistan. Journal of Nepal Geological Society, 15: 9-14.

[25] Schieber J., 2002. Sedimentary pyrite: a window into microbial past. Geology, 30: 531-534.

[26] Shah, S. M. I., 1970. Memoirs of the Geological Survey of Pakistan, GSP, 12, 79-80. 